\title{
THE DESCRIPTION OF SMOKING DEGREE BASED ON BRINKMAN INDEX IN PATIENTS WITH LUNG CANCER
}

\author{
Gambaran Derajat Merokok Berdasarkan Indeks Brinkman Pada Pasien Kanker Paru
}

\author{
Dessy Arumsari ${ }^{1}$, Santi Martini ${ }^{2}$, Kurnia Dwi Artanti ${ }^{3}$, Sri Widati ${ }^{4}$ \\ ${ }^{1}$ Public Health Faculty, Universitas Airlangga, dessy.arumsari-2015@ @km.unair.ac.id \\ ${ }^{2}$ Department of Epidemiology, Public Health Faculty, Universitas Airlangga, santi-m@ fkm.unair.ac.id \\ ${ }^{3}$ Department of Epidemiology, Public Health Faculty, Universitas Airlangga, kurnia-d-a@ @km.unair.ac.id \\ ${ }^{4}$ Department of Health Promotion and Behavior, Public Health Faculty, Universitas Airlangga, sri- \\ widati@fkm.unair.ac.id \\ Corresponding Author: Santi Martini, santi-m@fkm.unair.ac.id, Department of Epidemiology, Public Health \\ Faculty, Universitas Airlangga, Ir. H. Soekarno Street, Mulyorejo, Surabaya City, East Java, Indonesia, Postal \\ Code 60115
}

\section{ARTICLE INFO \\ Article History: \\ Received March, $1^{\text {st }}, 2019$ \\ Revised form April, $5^{\text {th }}, 2019$ \\ Accepted May, $23^{\text {rd }}, 2019$ \\ Published online September, $30^{\text {th }}$, 2019}

\author{
Keywords: \\ the degree of smoking; \\ cigarretes; \\ risk factors; \\ brinkamn index; \\ lung cancer
}

\section{Kata Kunci:}

derajat merokok;

rokok;

faktor risiko;

index brinkman;

kanker paru

\begin{abstract}
Background: Smoking is a major risk factor that causes lung cancer. The high number of active smokers in developing countries is found in several countries; one of those countries is Indonesia. Purpose: The purpose of the study was to describe the degree of smoking based on brinkman index on lung cancer patients. Methods: It was a descriptive study. It employed cross sectional research design. The population in this study included lung cancer patients in Outpatient and Inpatient Dr. Soetomo Regional Public Hospital, Surabaya. The independent variable in this study was the degree of smoking. Whereas, the dependent variable in this study was lung cancer. Accidental sampling was used as the sampling technique of the study. The total sample were 31 respondents. The instrument used for collecting data was questionnaire containing the risk factors of lung cancer in November 2018. The categorization of smoking degrees used the Brinkman Index measurement. Data were processed by univariate analysis which was presented in the form of a frequency distribution table between variables. Results: Almost all of the respondents were on the age of $>40$ years $(90.30 \%)$ and male $(96.80 \%)$. The majority of respondents were senior high school graduates (38.70\%), and had other jobs (32.20\%). Almost half of the respondents were classified into heavy smoking degree according to the brinkman index (48.40\%). Conclusions: Some of cancer patients in Dr. Soetomo Regional Public Hospital Surabaya has a smoking degree of heavy category.
\end{abstract}

C2019 Jurnal Berkala Epidemiologi. Published by Universitas Airlangga.

This is an open access article under CC-BY-SA license (https://creativecommons.org/licenses/by-sa/4.0/)

\section{ABSTRAK}

Latar Belakang: Merokok merupakan faktor risiko utama yang menyebabkan penyakit kanker paru. Jumlah perokok aktif yang tinggi berada di negara berkembang yaitu salah satunya adalah Indonesia.

Tujuan: Penelitian ini bertujuan untuk mengetahui gambaran 
derajat merokok berdasarkan indeks brinkman pada pasien kanker paru. Metode: Jenis penelitian ini merupakan penelitian deskriptif. Desain penelitian yang digunakan yaitu cross sectional. Populasi pada penelitian ini adalah pasien kanker paru di Rawat Jalan dan Rawat Inap RSUD Dr. Soetomo Surabaya. Variabel independen dalam penelitian ini adalah derajat merokok. Variabel dependen dalam penelitian ini adalah kanker paru. Pada penelitian ini menggunakan teknik sampling yaitu accidental sampling. Jumlah sampel pada penelitian ini yaitu 31 responden yang memenuhi kriteria inklusi. Instrumen penelitian yang digunakan adalah kuesioner yang berisi faktor risiko kanker paru pada bulan November 2018. Pengkategorian derajat merokok menggunakan pengukuran Indeks Brinkman. Data diolah dengan analisis univariat disajikan dalam bentuk tabel distribusi frekuensi antar variabel. Hasil: Hampir seluruh responden berusia $>40$ tahun (90,30\%) dan berjenis kelamin laki-laki (96,80\%) Mayoritas responden merupakan lulusan SMA/Sederajat (38,70\%), dan memiliki pekerjaan lainnya (32,20\%). Hampir sebagian responden tergolong dalam derajat merokok berat menurut indeks brinkman (48,40\%). Kesimpulan: Hampir sebagian pasien kanker di RSUD Dr. Soetomo Surabaya memiliki derajat merokok dengan kategori berat.

(C2019 Jurnal Berkala Epidemiologi. Penerbit Universitas Airlangga. Jurnal ini dapat diakses secara terbuka dan memiliki lisensi CC-BY-SA (https://creativecommons.org/licenses/by-sa/4.0/)

\section{INTRODUCTION}

Cancer causes around 9.60 million people to die worldwide. Lung cancer causes more deaths than the three most common cancers combined (large intestine, breast, and prostate). It is a leading cancer killer in both men and women in the United States. It also occupied the top position as a cause of death from cancer in women in 1987 beyond breast cancer. Globocan estimates that 158,480 Americans are expected to die of lung cancer in 2016, accounting for around $27 \%$ percent of all cancer deaths (WHO, 2017). The prevalence of lung cancer in Indonesia occupies the first position in the top five diseases $(34.20 \%)$. The prevalence of lung cancer in women occupies the fourth position in the top five diseases in women with $13.60 \%$ (Ministry of Health RI, 2013).

One of the cancers that has the highest incidence in the world is lung cancer. According to WHO, the incidence of lung cancer is higher in men than women. This can be caused by more smoking behavior carried out by men. Cigarettes kill up to half of the users. More than 7 million people in the world die from consuming tobacco directly (active smokers). Smokers live in lowermiddle income countries with an amount of $\pm 80 \%$ from 1.10 billion (CDC, 2017). Tobacco use is a major cause of non-communicable diseases or preventable diseases globally and has been predicted to cause health problems such as cardiovascular disease and various types of cancer including lung cancer (WHO, 2017).

Smoking habits have become part of the lifestyle of the community. Cigarettes are processed by tobacco and they contain substances such as nicotine and tar with or without additives in the form of filters or non-filters produced by nicotiana plants or other species (President of RI, 2012). Smoking can cause various health problems. It is not the cause of an illness, but it contributes to the emergence of diseases to cause death (Kosasi, 2018).

There are various types of diseases that can be caused by smoking such as cardiovascular disease, cancer, blood vessel disorders, the respiratory tract and decreased fertility. Smoking is a major risk factor for lung cancer. In this case, cigarettes cause $80 \%$ and $50 \%$ of lung cancer cases in men and women. Men who smoke 23 times more at risk of lung cancer. Women are 13 times more at risk of developing lung cancer compared to women who have never smoked at all (Ministry of Health RI, 2013).

Almost every year, there are around 7 million people who die from cigarettes. About 6 million people are active smokers and around 890,000 are passive smokers (CDC, 2017). Smoking can cause 
disease and is dangerous for almost every organ in the body. The Center Disease Control (CDC) in 2017 estimates that $14 \%$ of all adults (34.30 million people) are active smokers consisting of $15.80 \%$ of men and $12.20 \%$ of women. Nearly 40 million US adults still smoke, and around 4.70 million high school students use at least one tobacco product, including e-cigarettes. There is an increase of more than 3800 smokers per day at $<18$ years old. According to the Tobacco Free Initiative (TFI), data show that the number of smokers per day for men is around $63.20 \%$ and for women $4.50 \%$ of the total smokers (over 15 years) in Indonesia (Drope \& Schluger, 2012). The prevalence of smoking in Indonesia in 2013 was $29.30 \%$ and there was a decline to $28.80 \%$ in 2018. The same thing also happened in East Java with the prevalence of smoking in 2013 amounting to $28.60 \%$ and decreasing to $28.20 \%$ in 2018 (Ministry of Health RI, 2013).

The WHO organization estimates that the number of people killed per year is around 427,948 people and the number of people who die per day due to smoking is $\pm 1,172$ people in 2008 in Indonesia. There are one billion people who will die from smoking if this trend continues. About $80 \%$ of the 1.10 billion smokers in the world live in lower-middle income countries such as Indonesia (Drope \& Schluger, 2012).

The higher the number of cigarettes is consumed per day and the longer time someone smokes, the higher risk of lung cancer they will have (President of RI, 2012). Based on preliminary studies on recapitulation data at Dr. Seotomo for the last 10 months in 2018, they indicated that there were 733 cases of lung cancer.

Based on the number of cigarettes smoked per day and the duration of smoking, the degree of smoking can be determined using brinkman index. The degree of smoking can increase the risk of lung cancer (Presiden of RI, 2012). Based on this background, the researcher intended to describe the degree of smoking based on brinkman index in lung cancer patients in Dr. Soetomo Regional Public Hospital Surabaya. This study aims to describe the degree of smoking in lung cancer patients in Dr. Soetomo Regional Public Surabaya.

\section{METHODS}

This research is a descriptive study to describe the degree of smoking in lung cancer patients at Dr. Soetomo Regional Public Hospital Surabaya by using a cross sectional study. The study was conducted in November 2018. The population in this study were lung cancer patients in Outpatient and Inpatient of Dr. Soetomo Regional Public Hospital Surabaya. In this study, there were inclusion and exclusion criteria. In particular, this study has inclusion criteria, namely lung cancer patients who have a history of active smokers. The number of subjects obtained in this study is part of the population that meets the inclusion and exclusion criteria using accidental sampling technique as many as 31 respondents.

The variables in this study were age, gender, last education, occupation, number of cigarettes, duration of smoking and degree of smoking. Age is grouped into 2 categories, namely $\leq 40$ years and $>40$ years. Then, the number of cigarettes consumed is grouped into 2 categories, $<10$ sticks and $>10$ sticks. Besides, smoking duration is grouped into 2 categories, namely $\leq 20$ years and $>$ 20 years. Further, smoking degree is grouped based on brinkman index categorized in mild, moderate and severe smoking degrees. Categorization is based on the product of the multiplication of the length of smoking (in years) with the number of cigarettes consumed per day. The results of the multiplication are classified into mild (1-199 points), medium (200-599 points), and heavy degrees ( $>600$ points). The longer someone smokes and the more cigarettes they consume per day, the heavier the degree of smoking will be. Some items contained in the questionnaire included smoking duration, age at first time smoking, and the number of cigarettes consumed per day.

The data collection technques of the study consisted of interview to respondents (interviews with guardians who know the history of respondents if respondents are in a condition unable to be interviewed), a questionnaire to obtain information about the characteristics of respondents (age, sex, education level, and type work), and risk factors for smoking such as smoking duration and the number of cigarettes consumed per day. Then, data were analyzed using univariate analysis. Univariate analysis was conducted to analyze each variable from the results of the study by looking at the frequency distribution of each variable.

\section{RESULTS}

\section{Description of Respondent's Characteristics}

In this study, it can be seen that most of the respondents' age was $>40$ years for 28 respondents $(90.30 \%)$. Whereas, the characteristic of respondents based on sex is the highest in men 
than women for 30 respondents $(96.80 \%)$. Based on education, it is the highest in high school/ equivalent graduates for 12 respondents $(38.70 \%)$. Based on type of work is the highest in the unemployed/ housewife type for 10 respondents (32.30\%) (Table 1).

Description of the Number of Cigarettes Consumed, Smoking Duration, and Degree of Smoking

Table 1 shows that the number of cigarettes consumed per day is divided into two categories, $<10$ sticks and $>10$ sticks. The results of the study showed that respondents' characteristics based on the number of cigarettes consumed per day indicated that most of the respondents sucked $>10$ cigarettes, which was 26 respondents (83.90\%). Whereas, based on smoking duration, it was found that the majority of respondents smoke with a span of $>20$ years as many as 23 respondents $(93.50 \%)$. Most of the respondents had a heavy smoking degree category which was 15 respondents $(48.40 \%)$, moderate smoking degree as many as 13 respondents (35.48\%), and mild smoking degree as many as 3 respondents $(16.20 \%)$.

\section{Table 1}

The Respondents Distribution of Frequency based on Age, Sex, Education, Type of Work, and Degree of Smoking

\begin{tabular}{|c|c|c|}
\hline Characteristics & $\mathrm{n}$ & $\%$ \\
\hline \multicolumn{3}{|l|}{ Age (Year) } \\
\hline$\leq 40$ & 3 & 9,70 \\
\hline$>40$ & 28 & 90,30 \\
\hline \multicolumn{3}{|l|}{ Sex } \\
\hline Male & 30 & 96,80 \\
\hline Female & 1 & 3,20 \\
\hline \multicolumn{3}{|l|}{ Recent Education } \\
\hline Uneducated & 0 & 0,00 \\
\hline Elementary/Equivalent & 11 & 36,50 \\
\hline Junior High School/Equivalent & 5 & 16,10 \\
\hline Senior High School/Equivalent & 12 & 38,70 \\
\hline College & 3 & 9,70 \\
\hline \multicolumn{3}{|l|}{ Type of Work } \\
\hline Government Employee & 1 & 3,20 \\
\hline Businessman/Entrepreneur & 6 & 19,40 \\
\hline Private Employee & 1 & 3,20 \\
\hline Farmer/Fish Farmer & 3 & 9,80 \\
\hline Merchant & 2 & 6,40 \\
\hline Unskilled Labor/ Servant/ Pedicaper & 0 & 0,00 \\
\hline Unemployed/ Housewive & 10 & 32,20 \\
\hline Student/Scholar & 0 & 0,00 \\
\hline Others & 8 & 25,80 \\
\hline \multicolumn{3}{|l|}{ Number of Cigarettes } \\
\hline$\leq 10$ pieces & 5 & 16,10 \\
\hline$>10$ pieces & 26 & 83,90 \\
\hline \multicolumn{3}{|l|}{ Smoking Duration } \\
\hline$\leq 20$ years & 2 & 6,50 \\
\hline$>20$ years & 29 & 93,50 \\
\hline \multicolumn{3}{|l|}{ Degree of Smoking } \\
\hline Mild (1-199 poin) & 5 & 16,20 \\
\hline Moderate (200-599 poin) & 11 & 35,48 \\
\hline Severe $(\geq 600$ poin $)$ & 15 & 48,40 \\
\hline Total & 31 & 100,00 \\
\hline
\end{tabular}




\section{DISCUSSION}

\section{Description of Respondent's Characteristics}

Most of the respondents's age is $>40$ years. This is in line with the research conducted by Akbar, Ermayanti, \& Harminarti (2016) which states that most lung cancer patients are at the age of $>40$ years. This can be caused by exposure to risk factors for a long time that the impacts finally arise at the old age.

This study is also reinforced by a study conducted by Ananda, Ermayanti, \& Abdiana (2018) which also states that most lung cancer patients are over 40 years old. The older a person gets, the lower the immunity, thus the lesser the improvement of deoxyribonucleic acid that leads to the loss of the human body regulatory system which facilitates carcinogenesis in the body (Bulan, Ratnawati, \& Wargasetia, 2017).

The majority of respondents in this study were male. This is supported by WHO data in 2017 which stated that the incidence of lung cancer mostly occurred in men rather than women (WHO, 2017). Research conducted by Permitasari, Satibi, \& Kristina (2018) stated that the total number of cancer cases in Indonesia in 2016 was 39,597 cases. The study also stated that lung cancer cases were mostly found in men for 24,599 and 14,998 in women. According to a study conducted by Hulma, Basyar, \& Mulyani (2014) and Hansen et al (2018) lung cancer patients were mostly men. Furthermore, research conducted by Herlina, Rahmalisa, \& Dewi (2014) and Siregar, Widyaningsih, \& Syahruddin (2016) also stated that the characteristics of lung cancer patients were mostly male. In addition, several other studies conducted by Ananda, Ermayanti, \& Abdiana (2018) and Islami, Torre, \& Jemal (2015) stated that lung cancer patients were mostly male.

Other studies conducted by Warma, Munir, \& Bebasari (2015) and Husen, Suharti, \& Hardian (2016) stated that the characteristic of most lung cancer patients was men. This can be derived from the fact that the number of men who smoke are higher than women. The study also underlined that the age of smoking in men is younger than in women. Factors that cause smoking in men may include gaining approval by social response policy, showing manhood or maturity, culture, distracting themselves from conversation or frustration and pride. Other influencing factors could be physiological factors such as nicotine addiction (Akbar, Ermayanti, \& Herminati, 2016).

This study shows that the majority of respondents have a history of recent education in high school or equivalent. Education is one of the matters that can develop a person's potential as much as possible to provide assistance for individual development. Lack of awareness of the importance of one's education will make it difficult for a person to understand a problem that occurs and vice versa (Herlina et al., 2014). A study conducted by Semana (2014) stated that most of the lung cancer patients had the latest education in high school/ equivalent. This is in contrast to the study conducted by Ernawati, Ermayanti, Herman, \& Russilawati (2019) stating that most of lung cancer patients were the graduates of secondary education or junior high school/ equivalent. Nevertheless, a study conducted by Herlina, Rahmalisa, \& Dewi (2014) and Husen, Suharti, \& Hardian (2016) revealed different results which showed that most of lung cancer patients were mostly the graduates of primary or elementary education/ equivalent.

Based on Table 1, it can be seen that most respondents or $32.20 \%$ are respondents who do not work or are housewives. Research conducted by Ernawati, Ermayanti, Herman, \& Russilawati (2019) stated that the majority of lung cancer patients did not work or were housewives. This shows that people who do not work or housewives that are not active smokers can be exposed to other people's cigarette smoke (passive smoking). The result of national basic health research in 2013 showed that around 890,000 people were exposed to other people's smoke (passive smoking). Exposure to cigarette smoke from other people or passive smoking is a combination of smoke released by tobacco products that are burned and cigarette smoke released by an active smoker. About 7,000 chemicals have been identified in passive smoking. There are 69 of the chemical materials for which several examples are carcinogens including arsenic, benzene, beryllium, chromium, and formaldehyde (Ministry of Health RI, 2013).

\section{Description of the Number of Cigarettes Consumed, Smoking Duration, and Degree of Smoking}

Most of respondents consume cigarettes for more than 10 sticks per day. This research is in line with previous research which stated that lung cancer patients consumed $>10$ cigarettes per day. This occurs since a person experiences nicotine addiction. In this case, smokers tend to increase the number of cigarettes consumed per day to meet the body's need for nicotine. When a cigarette is smoked, there are other ingredients that are 
harmful to the body such as tar. Tar enters the oral cavity as solid steam. The steam will then become cold. After cold, it will become dense and it will forms brown deposits on the surface of the teeth, respiratory tract and lungs (Semana, 2014).

More than half of the total number of respondents smoke for more than 20 years. This study is in accordance with previous research conducted by Herlina, Rahmalisa, \& Dewi (2014) which stated that lung cancer patients smoke in average for more than 20 years. The duration of a person's smoking will put an impact on his health problems. This is because the older a person, the lower the person's immunity towards disease. This means that a person who smokes is more at risk for lung cancer. Other studies that are in line with this research is a research conducted by Warma, Munir, \& Bebasari (2015) which also stated that lung cancer patients smoke with a span of $>20$ years.

Smoking is a form of maturity for some people. A person who smokes can be considered as an adult. Relationships with friends within their circles, such as the work and neighborhood circles are the supporting causes that contribute to influence a person to become a smoker (Amelia, Nasrul, \& Basyar, 2016).

The smoking habit was done for several reasons, starting from trying, imitating parents/ adults who smoke. This emerges curiosity and leads many people to want to smoke yet they do not know the side effects of smoking (Yulviana, 2015). A person's risk of developing lung cancer depends on the degree of smoking, which is influenced by the number of cigarettes smoked in a day, the age at the time of starting smoking, and the duration of smoking in the year (Sudaryanto, 2016). The results of national basic health research in 2013 showed that in the age group of 15-19 years or adolescence is the highest age when a person starts smoking. The impact of cigarettes will begin to be felt at an interval of 10 years to 20 years after usage. If someone starts smoking at the earlier age, it will be more difficult to stop smoking (Ministry of Health RI, 2013).

The degree of smoking can be measured by Brinkman Index value, namely the duration of smoking (how long someone has smoked) in units of year multiplied by the number of cigarettes smoked per day (Amelia et al., 2016). According to Table 1 , the respondents are smokers with heavy smoking category based on Brinkman Index $(48.40 \%)$. Moreover, the incidence of lung cancer is closely related to the length of nicotine consumption. If there is someone who has been exposed to nicotine for a long time, the higher the risk of addiction and the risk of nicotine in health. Some health problems caused by smoking include lung function disorders, cardiovascular disease, and circulatory system diseases (Kusumawardani, Rahajeng, Mubasyiroh, \& Suhardi, 2016).

A study conducted by Hulma, Basyar, \& Mulyani (2014) stated that most lung cancer patients were smokers with heavy smoking degree. This research is also supported by research conducted by Naser, Medison, \& Erly (2016) that the highest degree of smoking was the heavy smoking degree. However, this study is not in line with the research conducted by Sudaryanto (2016) and Laloan, Marunduh, \& Sapulete (2018) which stated that the highest degree of smoking was mild smoking. Moreover, research conducted by Tatun, Icksan, Syahruddin, \& Kekalih (2015) and Amelia, Nasrul, \& Basyar (2016) also showed different results that the highest degree of smoking was moderate smoking.

The heavy degree of smoking can be interpreted that the people who have a history of smoking by consuming a large number of cigarettes and having longer smoking period have higher risk of lung cancer than smoking with a greater number of cigarettes but not for a long time, thus within lung tissue, damage occurs on the air sac (alveoli) (Semana, 2014). The higher the degree of smoking, the greater the amount of cigarettes toxic that enters the body, especially in the respiratory tract. This causes a decrease in lung function that occurs faster than to non-smokers (Naser, Medison, \& Erly, 2016). This can intensify efforts to spread the message of smoking cessation among young people as a supporting effort that can be undertaken by health workers and stakeholders (Chandrupatla, Tavares, \& Natto, 2017).

\section{Research Limitation}

This research has limitations that are related to the number of research sample obtained during the research due to the limited number of lung cancer patients and some respondents who refused to be interviewed for various reasons.

\section{CONCLUSION}

Nearly all respondents were above 40 years old and were male. The majority of respondents are high school graduates or equivalent and have other jobs. Most cancer patients in Dr. Soetomo Regional Public Hospital Surabaya are smokers who are categorized as heavy smokers, thus it is 
expected that health workers are able to conduct health information about the dangers of smoking and lung cancer to patients and families of patients who are treated at the public hospital.

\section{ACKNOWLEDGEMENT}

I would like to express my gratitude to Dr. Soetomo Regional Public Hospital as the research location. Also thank you to the respondents who were willing to be interviewed. Moreover, thank you to all parties who had given their help for this research.

\section{REFERENCE}

Akbar, R., Ermayanti, S., \& Harminarti, N. (2016). The correlation between the incidence of pneumonia and the length of stay for lung cancer patients at Dr M Djamil Hospital Padang. Jurnal Kesehatan Andalas, 7(4), 513-520.

Amelia, R., Nasrul, E., \& Basyar, M. (2016). Correlation between degree of smoking based on brinkman index and hemoglobin level. Jurnal Kesehatan Andalas, 5(3), 619624.

Ananda, R. R., Ermayanti, S., \& Abdiana. (2018). Correlation between lung cancer staging and pain scale in lung cancer patients treated in the lung section of Dr. M Djamil Hospital Padang. Jurnal Kesehatan Andalas, 7(3), 430-435.

Bulan, I. A. K. T., Ratnawati, H., \& Wargasetia, T. L. (2017). An overview of lung cancer patients at Immanuel Bandung Hospital from January 2013 to December 2014. Journal of Medicine and Health, 1(6), 517-524.

CDC. (2017). Tobacco. USA: Centers for Disease Control and Prevention.

Chandrupatla, S. G., Tavares, M., \& Natto, Z. S. (2017). Tobacco use and effects of professional advice on smoking cessation among youth in India. Asian Pacific Journal of Cancer Prevention, 18(7), 1861-1867. https://doi.org/10.22034/APJCP.2017.18.7.1 861

Drope, J., \& Schluger, N. W. (2012). Tobacco atlas (6th ed.). Atlanta: American Cancer Society.

Ernawati, Y., Ermayanti, S., Herman, D., \& Russilawati. (2019). Risk factors for lung cancer in women treated in the Lung Section of Dr. RSUP M. Djamil Padang and Solok
General Hospital: case control research. Jurnal Kesehatan Andalas, 8(2), 1-8.

Hansen, M. S., Licaj, I., Braaten, T., Langhammer, A., Le Marchand, L., \& Gram, I. T. (2018). Sex differences in risk of smoking-associated lung cancer: results from a cohort of 600,000 Norwegians. American Journal of Epidemiology, 187(5), 971-981. https://doi.org/10.1093/aje/kwx339

Herlina, Rahmalisa, S., \& Dewi, Y. I. (2014). Correlation of smoking history with stage $\mathrm{Ca}$ lung. Jurnal Online Mahasiswa (JOM) Bidang Ilmu Keperawatan, 1(1), 1-6.

Hulma, M. A., Basyar, M., \& Mulyani, H. (2014). The correlation between the characteristics of patients with cytopathology in cases of pulmonary carcinoma treated at Dr. Rsup M. Djamil Padang. Jurnal Kesehatan Andalas, 3(2), 196-201.

Husen, A., Suharti, C., \& Hardian. (2016). Correlation between the degree of pain and the quality of life of lung cancer patients undergoing chemotherapy. Jurnal Kedokteran Diponegoro, 5(4), 545-557.

Islami, F., Torre, L. A., \& Jemal, A. (2015). Global trends of lung cancer mortality and smoking prevalence. Translational Lung Cancer Research, 4(4), 327-338. https://doi.org/10.3978/j.issn.22186751.2015.08.04

Kosasi, H. N. (2018). Correlation between conformity and stress with smoking behavior among female adolescent (students in Samarinda and Balikpapan city). Psikoborneo, 6(3), 1-7. https://doi.org/10.22216/jen.v2i1.1372

Kusumawardani, N., Rahajeng, E., Mubasyiroh, R., \& Suhardi. (2016). The correlation between exposure to cigarette smoke and a history of chronic obstructive pulmonary disease (COPD) in Indonesia. Jurnal Ekologi Kesehatan, 15(3), 160-166. https://doi.org/10.22435/JEK.V15I3.5889.16 $0-166$

Laloan, R. J., Marunduh, S. R., \& Sapulete, I. M. (2018). Correlation between smoking with erythrocyte index values (MCV, MCH, MCHC) in smoker students. Jurnal Medik Dan Rehabilitasi, 1(2), 1-6.

Ministry of Health RI. (2013). National basic health research report (Rskesdas) 2013. Jakarta. Ministry of Health Republic Indonesia.

Naser, F., Medison, I., \& Erly. (2016). Description of the degree of smoking in copd patients in 
the lung section of Dr. RSUP M. Djamil. Jurnal Kesehatan Andalas, 5(2), 306-311.

Permitasari, N. P. A. L., Satibi, S., \& Kristina, S. A. (2018). National burden of cancers attributable to secondhand smoking in Indonesia. Asian Pacific Journal of Cancer Prevention, 19(7), 1951-1955. https://doi.org/10.22034/APJCP.2018.19.7.1 951

President of RI. (2012). Indonesian regulation number 109 of 2012 concerning safeguarding materials containing addictive substances is tobacco products for health. Jakarta: The Government Republic of Indonesia.

Semana, A. (2014). Correlation between smoking habits and lung cancer in Dr. RSUP Wahidin Sudirohusodo Makassar 2013. Jurnal Media Keperawatan, 5(10), 57-65.

Siregar, Y. S., Widyaningsih, W., \& Syahruddin, E. (2016). Body mass index, percentage of skeletal muscle and albumin in non-small cell carcinoma lung cancer patients before and after chemotherapy. Jurnal Respirologi Indonesia, 36(2), 73-82.

Sudaryanto, W. T. (2016). The relationship between the degree of active, mild, moderate and severe smoking with oxygen saturation levels (SpO2). Jurnal Terpadu Ilmu Kesehatan, 6(1), 51-61.

Tatun, R., Icksan, A. G., Syahruddin, E., \& Kekalih, A. (2015). Thoracic CT scan according to cytology / histology type in lung cancer patients who smoke. EJKI, 3(3), 177185.

Warma, A., Munir, S. M., \& Bebasari, E. (2015). Description of the severity of smoking based on CO level in smokers at Lung Poly Arifin Achmad Hospital, Riau Province. Jom Fk, 2(2), 1-7.

WHO. (2017). Cancer. Geneva: World Health Organization.

Yulviana, R. (2015). Factors related to smoking habits in male adolecent of Class X and XI in State High School 6 Pekanbaru. Jurnal Kesehatan Komunitas, 2(6), 278-282. 